\title{
Using a fixed-wing UAS to map snow depth distribution: an evaluation at peak accumulation
}

\author{
Carlo De Michele ${ }^{1}$, Francesco Avanzi ${ }^{1}$, Daniele Passoni ${ }^{2}$, Riccardo Barzaghi ${ }^{1}$, Livio Pinto ${ }^{1}$, Paolo Dosso $^{3}$, \\ Antonio Ghezzi ${ }^{1}$, Roberto Gianatti ${ }^{4}$, and Giacomo Della Vedova ${ }^{4}$ \\ ${ }^{1}$ Politecnico di Milano, Department of Civil and Environmental Engineering, Piazza Leonardo da Vinci 32, 20133 Milan, Italy \\ ${ }^{2}$ University of Genova, Department of Civil, Chemical and Environmental Engineering, Via Montallegro 1, \\ 16145 Genoa, Italy \\ ${ }^{3}$ Studio di Ingegneria Terradat, Paderno Dugnano, Italy \\ 4 a2a Group, Grosio, Italy \\ Correspondence to: Carlo De Michele (carlo.demichele@polimi.it)
}

Received: 21 January 2015 - Published in The Cryosphere Discuss.: 20 February 2015

Revised: 2 February 2016 - Accepted: 12 February 2016 - Published: 4 March 2016

\begin{abstract}
We investigate snow depth distribution at peak accumulation over a small Alpine area $\left(\sim 0.3 \mathrm{~km}^{2}\right)$ using photogrammetry-based surveys with a fixed-wing unmanned aerial system (UAS). These devices are growing in popularity as inexpensive alternatives to existing techniques within the field of remote sensing, but the assessment of their performance in Alpine areas to map snow depth distribution is still an open issue. Moreover, several existing attempts to map snow depth using UASs have used multi-rotor systems, since they guarantee higher stability than fixed-wing systems. We designed two field campaigns: during the first survey, performed at the beginning of the accumulation season, the digital elevation model of the ground was obtained. A second survey, at peak accumulation, enabled us to estimate the snow depth distribution as a difference with respect to the previous aerial survey. Moreover, the spatial integration of UAS snow depth measurements enabled us to estimate the snow volume accumulated over the area. On the same day, we collected 12 probe measurements of snow depth at random positions within the case study to perform a preliminary evaluation of UAS-based snow depth. Results reveal that UAS estimations of point snow depth present an average difference with reference to manual measurements equal to $-0.073 \mathrm{~m}$ and a RMSE equal to $0.14 \mathrm{~m}$. We have also explored how some basic snow depth statistics (e.g., mean, standard deviation, minima and maxima) change with sampling resolution (from $5 \mathrm{~cm}$ up to $\sim 100 \mathrm{~m}$ ): for this case study, snow depth standard deviation (hence coefficient of variation) increases with de-
\end{abstract}

creasing cell size, but it stabilizes for resolutions smaller than $1 \mathrm{~m}$. This provides a possible indication of sampling resolution in similar conditions.

\section{Introduction}

The spatial distribution of snow depth and snow water equivalent, SWE, has been widely measured and modeled, both at the local, slope, and catchment scale (Grünewald et al., 2010). Modeling techniques include statistical approaches, such as Carroll and Cressie (1996), Elder et al. (1998), Erxleben et al. (2002), Anderton et al. (2004), Molotch et al. (2004), Dressler et al. (2006), López-Moreno and NoguésBravo (2006), Skaugen (2007), Bavera et al. (2014), and conceptual, or physically based models - e.g., Lehning et al. $(2006 ; 2008)$. These works have improved our knowledge about, e.g., the relevance of single forcings in determining the distribution of snow on complex terrains (Anderton et al., 2004). In addition, they provide an useful tool to estimate the impact of future modifications of climate on the Earth system (Bavay et al., 2009, 2013).

Running a model often needs input and evaluation data at fine temporal resolutions (e.g., daily or hourly). These can be obtained by means of automated devices, such as snow pillows (De Michele et al., 2013), cosmic ray counters (Morin et al., 2012) and ultrasonic depth sensors (Ryan et al., 2008). These devices are usually placed in areas that 
are believed to be suitable locations for representative measurements at wider scales (i.e., unaffected by local heterogeneity). Nonetheless, their spatial resolution is often sparse, while Grünewald and Lehning (2015) report that, usually, point stations on flat areas tend to overestimate catchment mean snow depth, and that representative cells are usually randomly located - i.e., impossible to be determined a priori. These represent important drawbacks of point weather stations in the study of snowpack dynamics (see Rice and Bales, 2010; Meromy et al., 2013; Grünewald and Lehning, 2015 and references therein). Moreover, such instruments are usually affected by systematic and random errors, that degrade the precision of measurements (Avanzi et al., 2014).

Consequently, increasing interest is nowadays growing around distributed measurements of snow extent, depth, and SWE (Dietz et al., 2012), able to substitute, or integrate, point, and usually sparse, measurements. Existing techniques include terrestrial or airborne laser scanning (e.g., Hopkinson et al., 2004; Deems et al., 2006, 2013; Prokop et al., 2008; Dadic et al., 2010; Grünewald et al., 2010, 2013; Lehning et al., 2011; Hopkinson et al., 2012; Grünewald and Lehning, 2015; Hedrick et al., 2015), SAR (synthetic aperture radar, Luzi et al., 2009), aerial photography (Blöschl and Kirnbauer, 1992; König and Sturm, 1998; Worby et al., 2008), time-lapse photography (Farinotti et al., 2010), and optical and micro-wave data from satellite platforms (Parajka and Blöschl, 2006; Dietz et al., 2012). The good performance of these methods has been widely discussed, but survey expenses are still a constraint (Hood and Hayashi, 2010). Recently, digital photogrammetry has emerged as a cheaper tool to perform these surveys: as an example, Nolan et al. (2015) have evaluated this methodology in three study cases in Alaska and have compared airborne measurements of snow depth with $\sim 6000$ manual measurements. They have found a standard deviation between these two data sets around $\pm 0.1 \mathrm{~m}$. Bühler et al. (2016) have applied a similar method in Switzerland and have estimated snow depth distribution with a root mean square error (RMSE) of $0.30 \mathrm{~m}$. This technique is therefore an accurate solution that may be used to obtain distributed information about snow depth dynamics at meter (or centimeter) resolution.

Traditional airborne photogrammetry is usually performed by manned aircraft and this increases its costs and limits the temporal resolution of surveys. Unmanned aerial systems (UASs, also known as drones) could potentially overcome these limitations. These systems provide an inexpensive airborne support for sensors operating at different wavelengths. A UAS can autonomously determine its own position in a 3-D reference, reproduce a pre-arranged photogrammetric flight, and reconstruct a high-resolution digital surface model (hereinafter, DSM) of a given area (Watts et al., 2012) by setting a suitable (low) flight height over the target (say, $\sim 100 \mathrm{~m}$ ). All these features can potentially enable automated, repeatable, cheap (Colomina and Molina, 2014) and low-risk surveys to be performed. Their use is nowa- days rapidly increasing (Eisenbeiss, 2009; Watts et al., 2012; Colomina and Molina, 2014). Some examples regard ecology (Dunford et al., 2009; Koh and Wich, 2012), coastal engineering (Delacourt et al., 2009), geomorphological mapping (Lejot et al., 2007; Hugenholtz et al., 2013) or dust detection on snow (Di Mauro et al., 2015), see Colomina and Molina (2014) for an exhaustive review. In optical surveys, they usually adopt compact digital cameras, due to the limited payload (say $\sim 10^{2} \mathrm{~g}$ ). Nonetheless, these are affected by higher deformations as compared with those of photogrammetric calibrated cameras (Pollefeys et al., 1999; Remondino, 2006; Stretcha et al., 2010; Sona et al., 2014). Performing photogrammetric surveys using UASs may therefore represent a definitive solution to the problem of mapping snow depth with fine spatial and temporal resolutions. In the last few months, some early attempts, mainly using multi-rotor devices, have been published (Vander Jagt et al., 2015; Bühler et al., 2016) and they show promising results. Using multirotor devices guarantees high safety conditions due to their stability and resistance to wind. Nonetheless, this limits the areal extension of UAS surveys due to logistical constraints (battery duration). Fixed-wing devices may on the contrary perform larger investigations, but they need stable wind conditions and regular topography for landing operations.

Here, we investigate the possibility of using a fixedwing UAS to measure snow depth patterns at peak accumulation within a small mountainous basin, using centimeter/decimeter resolution. We chose as a field test the bare plateau around Lake Malghera, within the western Val Grosina Valley (around $2300 \mathrm{~m}$ a.s.l.), northern Italy. A double airborne survey of this area was designed. During the first one, the DSM of the ground was mapped, while during the second one, at peak accumulation, the same area was surveyed again to determine the DSM of the snow cover. A preliminary performance evaluation of this technique was operated using manual probe measurements at 12 points within the study domain.

\section{The study area}

The case study is located in the western Val Grosina Valley, Lombardy region, northern Italy. It is a small plateau located near to Lake Malghera, $\sim 46^{\circ} 20^{\prime} 2^{\prime \prime} \mathrm{N}, \sim 10^{\circ} 7^{\prime} 14^{\prime \prime} \mathrm{E}$, $2320 \mathrm{~m}$ a.s.l. The approximate extent of the study area is $0.3 \mathrm{~km}^{2}$, see Fig. 1. This figure includes also a topographic map of bare soil, produced by the local regional administration (Lombardy region).

This site is characterized by sparse grass coverage and rocks, with no tree, firn, or glacier ice. As a result, ground surface is bare during summer and autumn. Topography is relatively homogeneous and marked by frequent gullies and crests. Site aspect is northeast, whereas the average slope in the NE-SW direction is $\sim 14 \%$. Snow conditions are generally undisturbed, given site elevation and inaccessibility dur- 

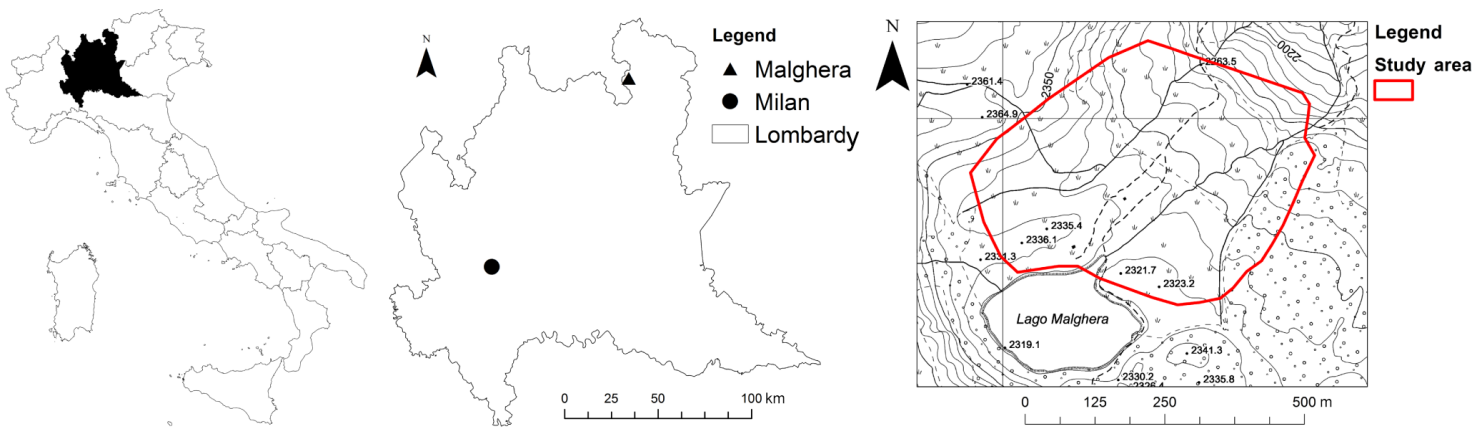

Figure 1. Location of the study area in western Val Grosina Valley, Lombardy region, northern Italy. The right panel shows a topographic map of the area, with isolines every $10 \mathrm{~m}$ and the elevation (in meters) of some points of interest. Topographic map from http://www.geoportale. regione.lombardia.it/.

ing winter. During our surveys, the only (visible) perturbation of snow was represented by unsystematic ski traces.

\section{Methods}

\subsection{Design of the surveys}

We design our study test to map snow depth distribution at peak accumulation. For this purpose, two different surveys are needed: one before accumulation starts (snow is absent and the survey can therefore map bare soil) and another one at peak accumulation. The first survey of the study area was performed on 26 September 2013, while the second survey was operated on 11 April 2014.

We used a light-weight fixed-wing SwingletCAM system $\left(\right.$ SenseFly $\left.{ }^{\circledR}\right)$. This device is characterized by limited weight $(\sim 500 \mathrm{~g})$ and size (wingspan of $80 \mathrm{~cm}$ ). These features make it suitable for performing photogrammetric flights over limited areas (about $1 \mathrm{~km}^{2}$ ) at a very high spatial resolution (3-7 cm of ground sample distance - GSD). The device is mainly made by an expanded polypropylene (EPP) foam, a carbon structure and composite parts. The propulsion is electric, with a maximum flight time around $30 \mathrm{~min}$. The nominal cruise speed is $\sim 36 \mathrm{kmh}^{-1}$, with a wind resistance up to $25 \mathrm{~km} \mathrm{~h}^{-1}$ and a radio link range up to $1 \mathrm{~km}$ from the master station on the ground. The SwingletCAM is able to perform pre-planned flights in a fully automated mode, since it continuously analyzes data from the onboard GPS/IMU system. However, the operator can always recover full control of the system. It incorporates a compact camera Canon Ixus 220HS (12 Mp and fixed focal length of $4.0 \mathrm{~mm}$ ) which can acquire images at a GSD of some centimeters (depending on flight height). The camera uses a bandpass filter for the three colors RGB. These are placed ahead of the complementary metal-oxide-semiconductor (CMOS) according to a Bayer filter.

In these two field surveys, the GSD was set to $4.5 \mathrm{~cm}$, since such a value enables to perform a survey at a flying elevation
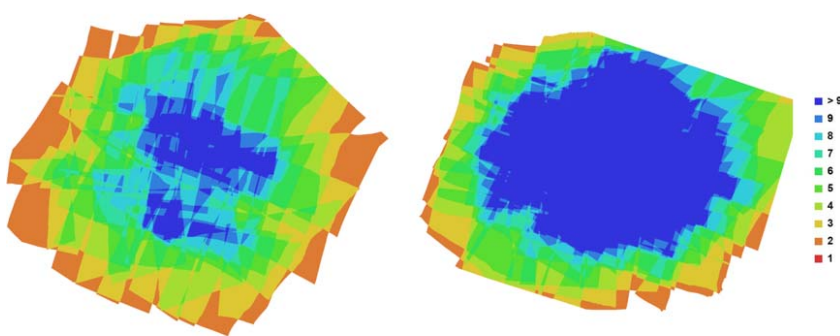

Figure 2. Camera images and their overlaps during each of the two surveys. The left panel corresponds to the survey made during September 2013, while the right panel corresponds to the survey made in April 2014. The legend indicates the number of images covering each area.

of around $130 \mathrm{~m}$ above ground surface (the complete range of the height values is between 130 and $135 \mathrm{~m}$ ). This is a good safety condition for this UAS device in a mountain area that is potentially subjected to strong winds. To gain the maximum stereoscopy and to avoid uncovered areas, forward and side overlaps were set to $80 \%$. Following this approach, from six to seven strips were necessary to cover the area of interest.

\subsection{Digital surface model production}

For both the surveys, the flight lasted around 15-20 min; Fig. 2 reports the location of camera photos and their overlap. The left panel regards the survey made during September 2013, while the right panel refers to the survey performed during April 2014. Colors indicate the number of images covering each point of the study area. It is well known that the precision in coordinate estimation increases with an increasing number of images in which a point is present (Remondino and El-Hakim, 2006). In this respect, most of the study area has been imaged at least by three or four images. Clearly, the overlap increases at the center of the study area. In that area, points have been imaged by a number of images $\geq 9$. 
In the survey made on 26 September 2013, the UAS collected a block of 47 images divided into six strips. Due to the high image overlap, all the ground points are visible in many images (from 3 to 9). Thirteen pre-signalized ground control points (henceforth, GCPs), measured through GPS rapid static survey, enabled the referencing of the block and the accuracy analyses. The standard deviation of the three coordinates of GCPs are around $3 \mathrm{~cm}$ in the horizontal components, and $5 \mathrm{~cm}$ in the vertical one.

In the survey performed on 11 April 2014, the UAS collected a block of 84 images divided in 12 strips (six regular strips as in the autumn survey plus six cross-strips). Fourteen pre-signalized GCPs, measured through a GPS static survey and theodolite, enabled the referencing of the block. This set of GCPs is different from the one used during the first survey. We chose points that were reasonably distributed over the area, and we referred them to the same reference frame. Based on this survey, GCPs coordinates have been estimated with a standard deviation of about $1 \mathrm{~cm}$.

The blocks of images were processed using Agisoft Photoscan. This is a 3-D modeling software that enables the exterior orientation of large data sets, by carrying out the image relative orientation, together with the self-calibration, in an arbitrary reference system, which is often obtained using a minimum constraint coming from the approximate orientation provided by telemetry. Details about the processing procedure can be found in the Photoscan user manual (Agisoft, 2014), as well as at the Agisoft website (http://www.agisoft. com/). Moreover, several papers are available that describe the use of Photoscan to generate 3-D models of surfaces (Verhoeven, 2011; Koutsoudis et al., 2014). Firstly, for each block of images, the position of the camera for each image is determined by searching common points on the images. Then, the extraction of topographic points (which represent a cloud of points) and the rejection of outliers are made for each survey. The subsequent use of GCPs allows translating and rotating the photogrammetric blocks in a specific reference frame - i.e., ETRF2000. Then, starting from the cloud of points, DSMs at different spatial resolutions are extracted by generating a polygonal mesh model from the cloud data through interpolation. By making the differences of the two DSMs (at the same spatial resolution), maps of snow depth distribution can be obtained.

In this application, we considered spatial resolutions of 5,10 , and $20 \mathrm{~cm}$. These are very fine with respect to other existing data sets of snow depth (see López-Moreno et al., 2015 as an example). However, UASs make it possible to collect high-resolution data with sensible lower effort than, e.g., manual probing; this can provide useful indications for future surveys using the same devices. Increasing spatial resolution means that computational/logistical costs are higher: for instance, flight elevation must be lower. Note that $5 \mathrm{~cm}$ is probably a proper lower limit given the typical size of snow grains/clusters (Fierz et al., 2009).

\subsection{Point data collection}

During the survey performed in April 2014, 12 point manual measurements of snow depth were operated using probes. Locations of these measurements were randomly chosen, but they were distributed as much as possible over the study area. We have used these data to perform a preliminary evaluation of UAS performance in retrieving point values of snow depth, as already done by, e.g., Bühler et al. (2016). In particular, we have calculated the mean, standard deviation and RMSE of the differences between manual and UAS-based estimations of snow depth. Note that point locations were chosen neglecting spatial correlation in snow depth.

Snow depth distribution is usually marked by strong spatial variability at small scales (Grünewald et al., 2010; López Moreno et al., 2013; López-Moreno et al., 2015; Mott et al., 2014) and this hampers our evaluation since coordinates of probe data must be collected with a very high spatial precision due to the spatial resolution we have considered. For this purpose, coordinates were obtained by total station theodolite observations referred to GPS baselines that were surveyed by static approach ( $40 \mathrm{~min}$ sessions). The horizontal accuracy of the obtained coordinates is of the order of $2-3 \mathrm{~cm}$ (i.e., comparable with the spatial resolution of the DSM at the maximum resolution). This procedure makes it difficult to collect a massive database of evaluation data, but guarantees a very high spatial precision in coordinates retrieval. On the other hand, this amount of data is clearly reduced in comparison with previous evaluations of remote sensing techniques by, e.g., Prokop et al. (2008), Nolan et al. (2015), and Bühler et al. (2016). Photogrammetry is rather traditional, and this increases our confidence towards its performance. However, we stress that this amount of points allows only a preliminary evaluation, since the main focus here is on using a fixed-wing UAS in mountain areas to map snow depth, and that more data are needed to perform a definitive evaluation.

On the same day, a snow pit was excavated, and a snow density profile was measured through gravimetry (using a cylindrical sample holder, $15 \mathrm{~cm}$ long and with a $7.5 \mathrm{~cm}$ diameter). Measurements were taken at $\sim 20 \mathrm{~cm}$ intervals along $210 \mathrm{~cm}$ of snow depth at that point. Density values spanned between 330 and $570 \mathrm{~kg} \mathrm{~m}^{-3}$ (mean value $\sim 450 \mathrm{~kg} \mathrm{~m}^{-3}$ ).

\subsection{Spatial sampling vs. snow depth statistics and volume}

In the following, we will consider three different tests to assess how spatial sampling affects snow depth measurement at peak accumulation. As a first step, we have estimated some basic snow depth statistics - i.e., minimum, mean, and maximum snow depth and total snow volume, using the three snow depth maps we obtained directly from the survey cloud of points (i.e., maps at 5, 10, and $20 \mathrm{~cm}$ resolution). This aims 


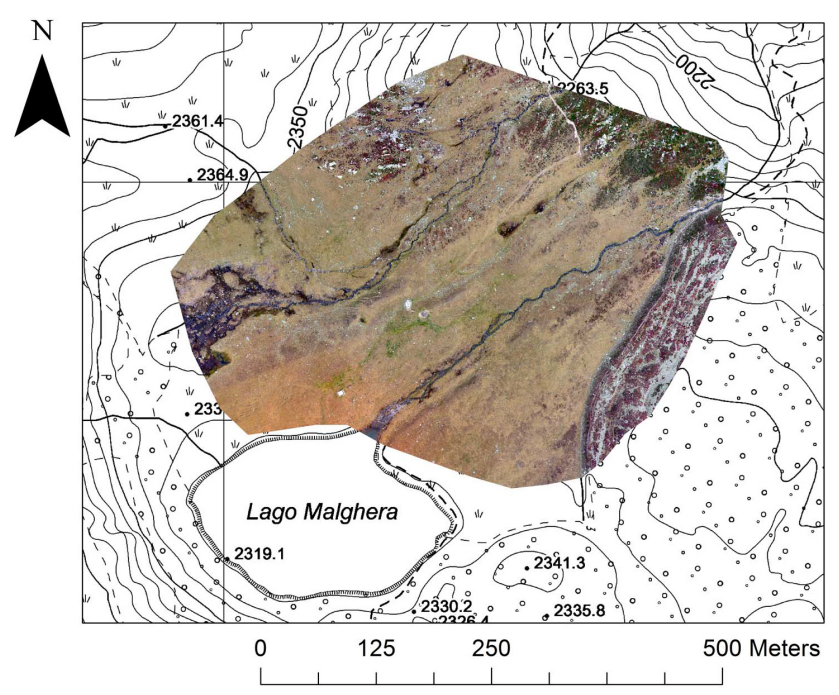

Figure 3. Orthophoto of the survey performed on 26 September 2013.

at clarifying any benefit to increasing spatial resolution from decimeter to centimeter scale.

As a second step, we have repeatedly resampled the snow depth map using an increasing cell size, starting from $5 \mathrm{~cm}$ resolution (e.g., Cline et al., 1998). For this purpose, we have progressively aggregated cells by doubling cell size and estimating snow depth for each new cell using the mean of the snow depth of the aggregated cells. Consequently, we have produced estimated snow depth distributions using the following cell sizes: $5 \mathrm{~cm}$ (the original one), 10, 20, 40, 80, 160, $320,640,1280,2560,5120,10240 \mathrm{~cm}$. Missing values have been disregarded. We have then calculated mean snow depth $(\mu)$, standard deviation $(\sigma)$, coefficient of variation $(\mathrm{CV})$ and minimum(maximum) value within each of these maps. The main purpose of this calculation is assessing how snow depth variability evolves with increasing/decreasing cell size.

As a third step, we have compared the estimates of snow volume by simple spatial interpolations of snow probe data with the distributed estimation of snow volume obtained using UAS. Different spatial interpolation methods have been considered for snow (Fassnacht et al., 2003; López-Moreno and Nogués-Bravo, 2006; Marsh et al., 2012); we will consider here inverse distance weighting, the Thiessen method, and ordinary kriging. In addition, we will consider also the arithmetic mean of snow depth measured at probes. We have chosen these techniques since they are easy to be interpreted and are among the most used techniques in interpolation problems. The application of more complex techniques (e.g., co-kriging) is also hampered by the paucity of ground truth data collected.

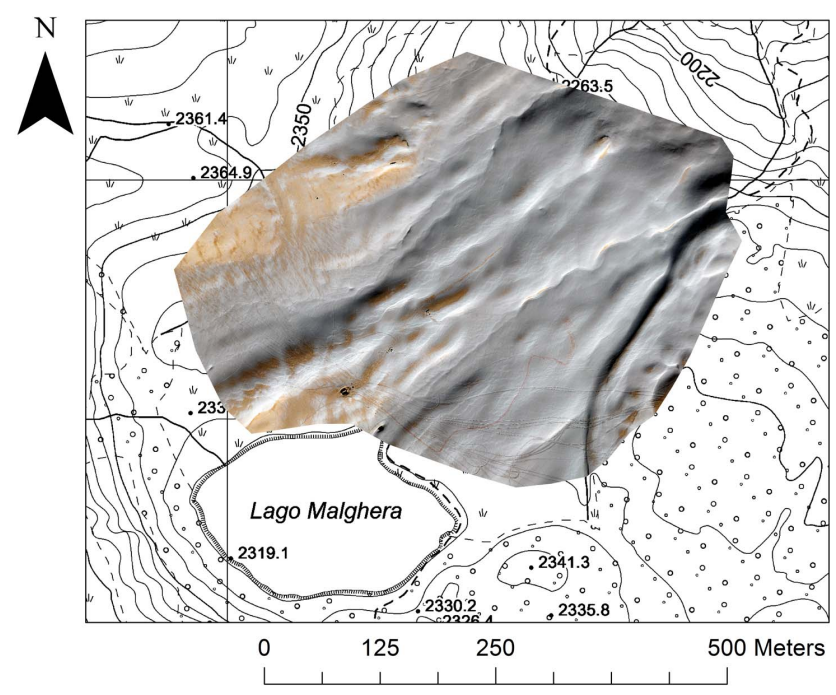

Figure 4. Orthophoto of the survey performed on 11 April 2014.

\section{Results and discussion}

\subsection{DSM evaluation}

Figures 3 and 4 report the two orthophotos of autumn and spring surveys. Figure 5 describes the related DSMs, both characterized by a pixel size of $5 \mathrm{~cm}$. Red lines depict contour lines (10 $\mathrm{m}$ interval).

The autumn DSM (Fig. 5a) shows good coherence with the topographic map reported as background. For example, rivers and Malghera Lake outlet are correctly located. We have carried out a quantitative evaluation of this DSM by using as an independent map of the area, a $5 \times 5 \mathrm{~m}^{2} \mathrm{DSM}$ of the Lombardy Regional Authority, which is based on the digitalization of the 1:10000 map reported as background in all the figures of this paper. In particular, Fig. 6a reports a map of the differences between the UAS-based DSM and this reference DSM. Maximum and minimum differences are 5.58 and $-6.61 \mathrm{~m}$, whereas the mean difference and the standard deviation are -0.92 and $1.63 \mathrm{~m}$. The precision of original contours in the $1: 10000$ map by the regional administration is $\pm 2.5 \mathrm{~m}$ : differences in the range $\pm 7.5 \mathrm{~m}$ between these two DSMs are therefore within the range \pm 3 standard deviations, i.e. within tolerance. The statistics of the differences are therefore coherent with the accuracy of the DSM. In Fig. 6b, UAS-based contours (in red) are directly superimposed to the contours of the topographic map. This comparison shows that the agreement increases with steeper terrains.

An evaluation of the spring survey (Figs. 4 and 5b) is less straightforward due to lack of independent maps of snow surface at this site. The snow depth surface on this area is marked by patchy coverage of sand dust transported by wind storms. This is visible as brown areas in the orthophoto (Fig. 4), and has helped referencing the images of the spring survey since it provided common points on photographs. In 


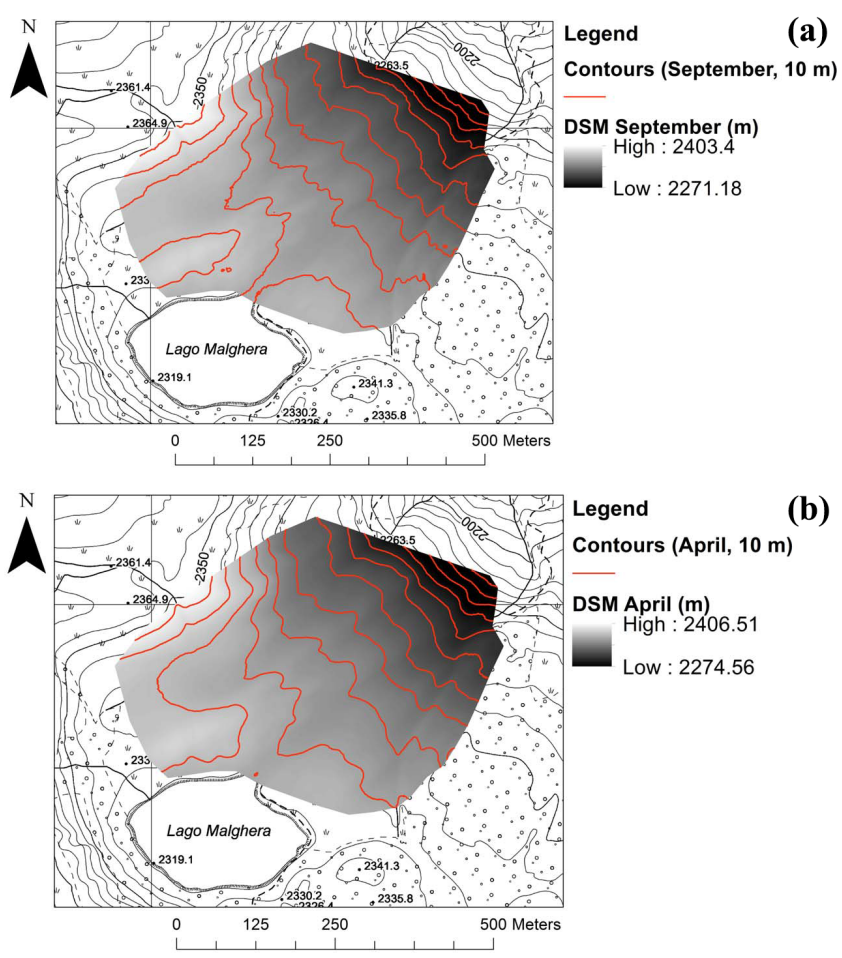

Figure 5. Digital surface model (DSM) of the two surveys. (a) DSM of the survey performed during September 2013. (b) DSM of the survey performed during April 2014. For both DSMs, a $5 \times 5 \mathrm{~cm}^{2}$ cell size has been used.

fact, the density of points obtained within one of these brown areas (randomly chosen) is equal to 44.7 points $\mathrm{m}^{-2}$, whereas the density of points in one white area (i.e., an area with no dust, again randomly chosen) is 35.9 points $^{-2}$. However, we note that within our study case several additional topographic irregularities (e.g., snow depressions near rivers, emerging rocks or buildings) may help as well. The DSM shows contour lines which are different from those obtained during the September survey. This is an effect of snow depth presence on the ground; this causes a slight reduction in topography irregularities too.

\subsection{Snow depth map}

Figure 7 reports a map of snow depth distribution over the study area (at $5 \mathrm{~cm}$ resolution) and the location of the 12 manual measurements. Snow depth shows a remarkable micro-topographic variability (i.e., at distances comparable with map resolution), although this area is rather limited in extension and characterized by bare soil. Most of the central study area is characterized by an alternation of low and high snow depth values. Clusters of high values of snow depth correspond to rivers' location or depressions in microtopography. In contrast, low snow depths are observed on topographic local maxima, probably because of wind effects. The legend scale shows that micro-topographic differences
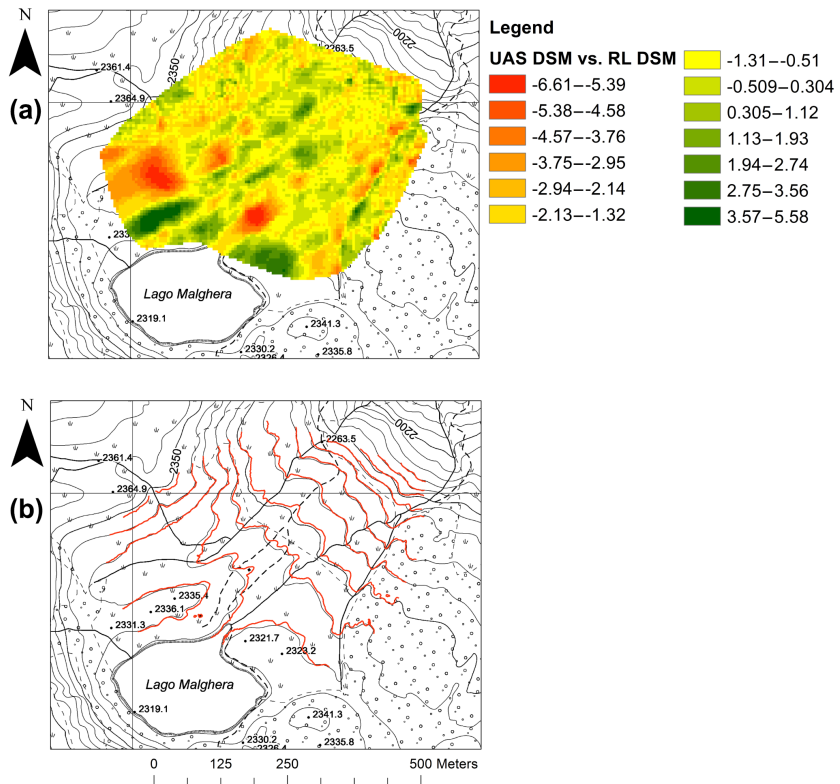

Figure 6. Validation of the DSM of bare soil (September 2013). (a) Map of the differences between the UAS-based DSM and an existing DSM provided by the Lombardy Regional Authority $(5 \mathrm{~m}$ cell size, differences in $\mathrm{m}$ ). (b) Comparison between UAS-based contours $(10 \mathrm{~m}$, in red) and those reported in the topographic map of the area (in black).

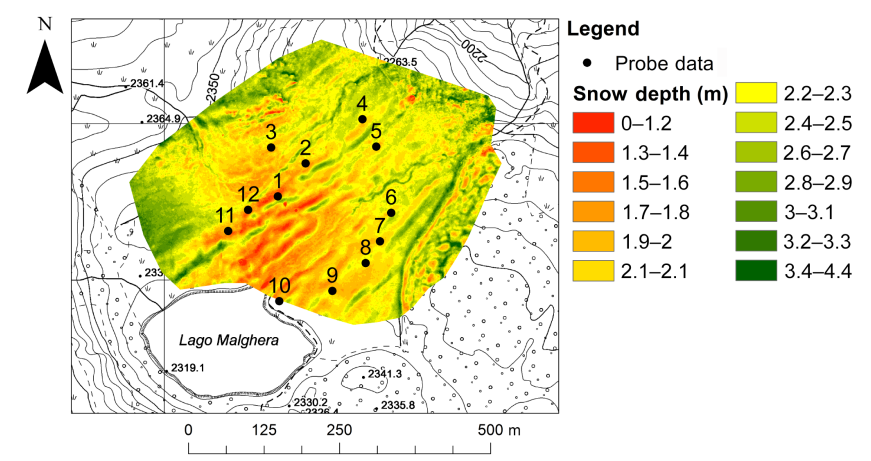

Figure 7. A map of snow depth distribution over the study area, obtained by means of difference of the elevations of the maps reported in Fig. $5\left(5 \times 5 \mathrm{~cm}^{2}\right.$ cell size $)$. Different colors indicate different values of snow thickness (see the legend scale). Black dots indicate the location of the 12 manual measurements of snow depth (see Table 1 for IDs of the points).

can be equal to $\sim 2-3 \mathrm{~m}$. This illustrates the relevant variation of accumulation dynamics of snow depth (Nolan et al., 2015), and the scarce representativeness of point measurements (Grünewald and Lehning, 2015).

We report in Table 1 a comparison between manual $\left(H_{\mathrm{M}}\right)$ and UAS based (HUAS $)$ snow depth measurements. Manual measurements are associated with a standard resolution of $\pm 1 \mathrm{~cm}$. Differences span -0.21 and $0.08 \mathrm{~m}$, whereas 
Table 1. Comparison of manual $\left(H_{\mathrm{M}}\right)$ and UAS $\left(H_{\mathrm{UAS}}\right)$ snow depth measurements.

\begin{tabular}{|c|c|c|c|c|}
\hline ID & $\begin{array}{l}H_{\mathrm{M}} \\
(\mathrm{m})\end{array}$ & $\begin{array}{c}H_{\text {UAS }} \\
(\mathrm{m})\end{array}$ & $H_{\mathrm{M}}-H_{\mathrm{UAS}}$ & $H_{\mathrm{UAS}} / H_{\mathrm{M}}$ \\
\hline 1 & 1.48 & 1.40 & 0.08 & $94.6 \%$ \\
\hline 2 & 2.07 & 2.06 & 0.01 & $99.5 \%$ \\
\hline 3 & 1.75 & 1.96 & -0.21 & $112 \%$ \\
\hline 4 & 1.88 & 2.05 & -0.17 & $109 \%$ \\
\hline 5 & 1.68 & 1.93 & -0.25 & $114 \%$ \\
\hline 6 & 1.85 & 2.13 & -0.28 & $115 \%$ \\
\hline 7 & 1.96 & 2.03 & -0.07 & $103 \%$ \\
\hline 8 & 2.11 & 2.17 & -0.06 & $102 \%$ \\
\hline 9 & 1.91 & 1.96 & -0.05 & $102 \%$ \\
\hline 10 & 1.89 & 1.81 & 0.08 & $95.7 \%$ \\
\hline 11 & 1.45 & 1.49 & -0.04 & $102 \%$ \\
\hline 12 & 1.60 & 1.52 & 0.08 & $95.0 \%$ \\
\hline \multirow{3}{*}{\multicolumn{3}{|c|}{$\begin{array}{l}\text { Average difference }(\mathrm{m}) \\
\text { SD difference }(\mathrm{m}) \\
\operatorname{RMSE}(\mathrm{m})\end{array}$}} & -0.073 & \\
\hline & & & 0.128 & \\
\hline & & & 0.143 & \\
\hline
\end{tabular}

the average difference between measurements is equal to $-0.073 \mathrm{~m}$, with an associated standard deviation of $0.128 \mathrm{~m}$. The RMSE is equal to $0.143 \mathrm{~m}$. These statistics are coherent with previous attempts at using a combination between digital photogrammetry and UAS to measure snow depth. As an example, Vander Jagt et al. (2015) found RMSEs equal to 0.096 and $0.184 \mathrm{~m}$ while mapping snow depth distribution in Tasmania within an area of $\sim 0.007 \mathrm{~km}^{2}$ (differences in performance depend on the methodology considered during bundle adjustment), whereas Bühler et al. (2016) recently reported an RMSE around $0.07-0.30 \mathrm{~m}$ (depending on ground properties - e.g., the presence of vegetation underneath snow) when mapping snow depth in two study sites in Switzerland (areas spanning 0.363 and $0.057 \mathrm{~km}^{2}$ ). A similar performance has been recently reported also for digital photogrammetry surveys of snow distribution using manned aircraft (Nolan et al., 2015; Bühler et al., 2016).

Thus, this survey provides evidences that UASs seem able to locally estimate the snow depth values with a precision of $\sim 10 \mathrm{~cm}$. Errors could be explained by slight differences (at centimeter scale) in the position of manual measurements and UAS estimates, instrumental resolution, or vegetation effects, as already reported by Vander Jagt et al. (2015) and Bühler et al. (2016). However, the amount of points data we have used is very small, and snow depth at probe positions varies between 1.48 and $2.11 \mathrm{~m}$, which represents a reduced variability with respect to the complete range of variation of UAS snow depth values. These represent important limitations of this study: additional investigations are necessary to extensively assess UAS performance in the case of, e.g., shallow or patchy snow cover conditions (see Sect. 4.4).
Table 2. Snow volume calculation using UAS measurements and three different spatial resolutions: $5,10,20 \mathrm{~cm}$.

\begin{tabular}{llllll}
\hline $\begin{array}{l}\text { Resolution } \\
(\mathrm{cm})\end{array}$ & $\begin{array}{l}\text { Pixels } \\
(\#)\end{array}$ & $\begin{array}{l}\bar{H} \\
(\mathrm{~m})\end{array}$ & $\begin{array}{l}H_{\max } \\
(\mathrm{m})\end{array}$ & $\begin{array}{l}H_{\min } \\
(\mathrm{m})\end{array}$ & $\begin{array}{l}V \\
\left(\mathrm{~m}^{3}\right)\end{array}$ \\
\hline 5 & 81918743 & 2.26 & 4.21 & -0.22 & 463652.3 \\
10 & 20479686 & 2.26 & 4.35 & -0.24 & 462957.8 \\
20 & 5119921 & 2.27 & 4.15 & -0.24 & 464093.0 \\
\hline
\end{tabular}

\subsection{Snow depth statistics}

\subsubsection{Test 1: spatial resolution vs. snow depth distribution}

Table 2 proposes a comparison in terms of number of pixels, average/maximum/minimum snow depth and snow volume estimated according to the DSMs at 5,10 , and $20 \mathrm{~cm}$ that have been directly obtained from the cloud of points of this survey. Clearly, increasing spatial resolution from decimeter to centimeter scale would increase the number of pixels. Nevertheless, this seems to marginally affect the estimations of average/maximum/minimum snow depth or total snow volume. Based on these results, we do not see clear benefits in increasing cell size of snow depth maps from decimeter (10 or $20 \mathrm{~cm})$ to centimeter $(5 \mathrm{~cm})$ scale at peak accumulation. Clearly, keeping resolution at $20 \mathrm{~cm}$ may help limiting logistical/operational costs, as flight height is related to precision. Additional investigations on this point are proposed in the next section.

Note that minimum snow depth is systematically negative for all these three resolutions. These values were set to 0 in Fig. 7 for readability. Spurious negative snow depths have been already noted during photogrammetric surveys by, e.g., Nolan et al. (2015) and can be attributed to the effect of compressible vegetation (and instrumental precision). As Nolan et al. (2015) note, this effect hampers the general assumption that snow depth distribution can be simply obtained by differentiating two DSMs. A similar effect may be also the cause of the large differences between $H_{\mathrm{M}}$ and $H_{\mathrm{UAS}}$ at points from 3 to 6 in Table 1, that nonetheless lie in areas with scattered rocks, which may have caused additional noise in the DSM. During the autumn survey, we did not notice systematic presence of shrubs, bushes, or other vegetation types that might be compressed by snow in areas that were subsequently probed in April. This highlights the need for future investigations to address the issue of varying UAS precision with vegetation.

\subsubsection{Test 2: the effect of spatial sampling on snow depth statistics}

We report in Fig. 8 some examples of the snow depth maps we have obtained by progressively doubling the cell size of the original map at $5 \mathrm{~cm}$. In particular, we report maps with 

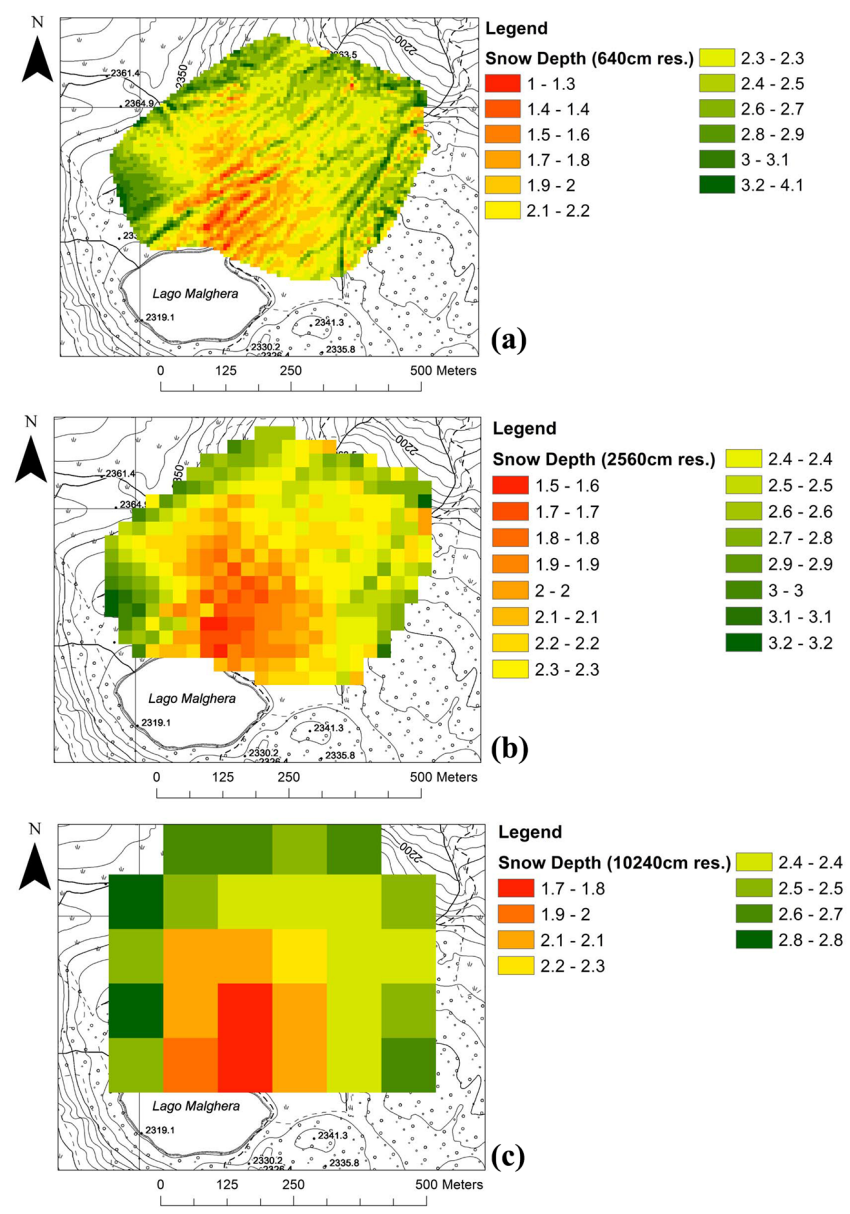

Figure 8. Rescaled maps of snow depth (in $\mathrm{m}$ ) at different cell sizes. (a) $640 \mathrm{~cm}$, (b) $2560 \mathrm{~cm}$, (c) $10240 \mathrm{~cm}$. See Sect. 4.3 .2 for details.

cells size equal to $640 \mathrm{~cm}$ (panel a), $2560 \mathrm{~cm}$ (panel b) and $10240 \mathrm{~cm}$ (panel c). The coarsest map ( $\sim 100 \mathrm{~m}$ resolution) retains only a small fraction of original spatial variability (i.e., a lower-than-average snow depth in the proximity of the Malghera Lake, and a greater-than-average snow depth on slopes). Most of the spatial patterns in snow depth are lost.

A spatial resolution of $10-100 \mathrm{~m}$ is much higher than the typical spatial density of instrumental networks that are currently implemented worldwide to monitor snow dynamics (e.g., Serreze et al., 1999). Such a cell size is also smaller than the ordinary resolution of satellite products (e.g., Dietz et al., 2012). In this perspective, UAS may be a valid intermediate step between point measurements of snow variables at high temporal resolutions (e.g., pillows or depth sensors) and satellites, which usually provide distributed information with low temporal and spatial resolution (see also Nolan et al., 2015 on this point). Our results show in fact that a metric (or lower) resolution provides relevant spatial patterns to describe the relation between topography and snow accumulation (Grünewald et al., 2010; Grünewald and Lehning, 2015).
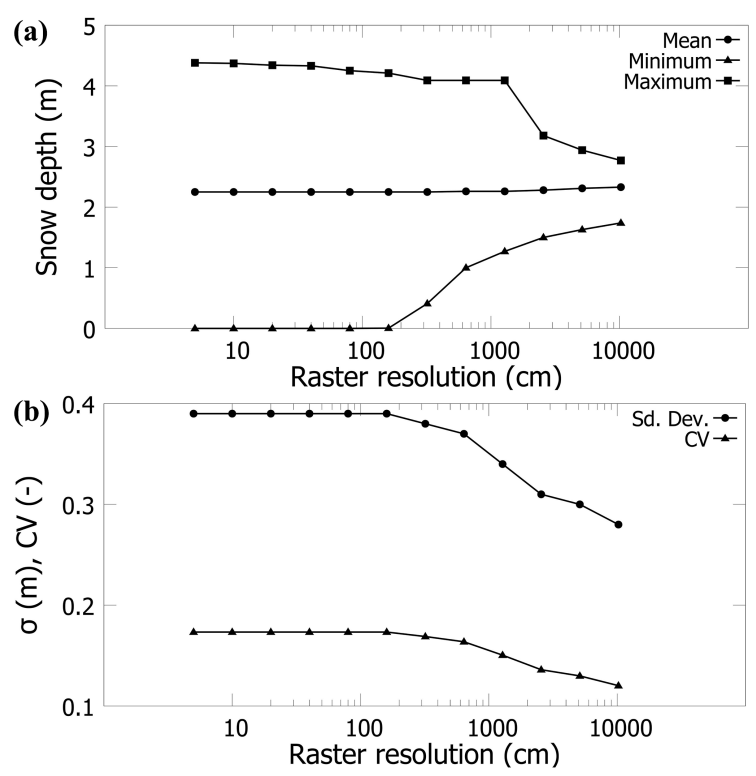

Figure 9. Snow depth statistics within the study domain as a function of map cell size. (a) Minimum, mean, and maximum snow depth; (b) snow depth standard deviation $(\sigma)$ and coefficient of variation $(\mathrm{CV})$.

Figure 9 reports statistics in terms of minimum, mean $(\mu)$, and maximum snow depth, its standard deviation $\sigma$, and the corresponding CV of each map, as a function of cell size. This figure reveals that $\mu$ is quite constant across all the resolutions (values range between 2.25 and $2.33 \mathrm{~m}$ ). This is probably due to the algorithm we used for this aggregation, that estimates the snow depth for an aggregated cell as the mean of the cells that are aggregated. Consequently, spatial differences are gradually homogenized when increasing the cell size. Minima and maxima are rather constant below $\sim 1.6 \mathrm{~m}$. In this range of resolution, maximum snow depth spans 4.38 and $4.21 \mathrm{~m}$, whereas minima are spuriously lower than zero, probably due to vegetation effects or instrument resolution (negative values set to zero in Fig. 9 for clarity). For larger cell sizes, these quantities start to converge towards the mean due to progressive homogenization.

An interesting result of Fig. 9 is that, within our case study, $\sigma$ presents a well-defined upper boundary (as well as $\mathrm{CV}$ ). In particular, it is minimum for coarser resolutions $(\sigma=0.28 \mathrm{~m}$ for a cell size equal to $10240 \mathrm{~cm})$, whereas it increases monotonically with smaller cell sizes $(\sigma=0.39 \mathrm{~m}$ for a cell size equal to $160 \mathrm{~cm}$ ). This effect may be due again to the methodology used for the aggregation, but it shows that increasing the spatial resolution of the survey makes it possible to add significant information, since this captures additional variability in snow depth. On the other hand, $\sigma$ stabilizes when cell size is $\leq 1 \mathrm{~m}$. The CV has similar dynamics. In the literature, it has been observed that snow depth variability increases with higher sampling resolutions (LópezMoreno et al., 2015), but, to our knowledge, few data sets 
are available with a sub-meter horizontal sampling resolution (Nolan et al., 2015). Consequently, it is not easy to compare this behavior with other analyses. These dynamics will be the object of future investigations since, if confirmed, they may define a threshold for sampling resolution when measuring snow depth during the accumulation season (say, $1 \mathrm{~m}$ resolution).

The range of $\mathrm{CV}$ that we have found here is lower than those reported by, e.g., López-Moreno et al. (2015), but seems in agreement with the results by López-Moreno et al. (2011) for a survey performed during January. Snow depth spatial variability increases with time during the year (Ménard et al., 2014; López-Moreno et al., 2015), due to local heterogeneity in ablation dynamics. It follows that a reduced $\mathrm{CV}$ at peak accumulation may be expected.

\subsubsection{Test 3: UAS-based volume of snow vs. spatial interpolation}

Table 3 reports the comparison between the estimated snow volume using a set of simple interpolation techniques of the 12 snow depth probes and the estimation of snow volume operated by the UAS system ( $5 \mathrm{~cm}$ resolution). Results show that the average difference between estimations by interpolation techniques and the snow volume estimated by the UAS system is equal to $\sim 21 \%$. In terms of absolute values, the average difference is $\sim 96350 \mathrm{~m}^{3}$. Considering an average bulk snow density of $450 \mathrm{~kg} \mathrm{~m}^{-3}$ (as measured in the snow pit), this would entail an absolute difference in SWE estimation of $\sim 43358 \mathrm{~m}^{3}$.

A $\sim 21 \%$ difference provides interesting suggestions about the possible impact of UAS for hydrologic applications, as interpolating points data has represented a widely used technique in snow hydrology for decades. In fact, such a high difference clarifies the benefits of using a distributed estimation of snow depth at high spatial resolution. However, the snow volume obtained by UAS is affected by uncertainties and noise and must not be considered as the best estimate among those reported in Table 3. For example, all interpolation techniques return an underestimated volume of snow, but this is a case-specific result, that is due to the choice of probe positions. In fact, Fig. 7 shows that manual measurements were accidentally taken in areas that were mainly characterized by shallow snow cover.

\subsection{Using fixed-wing UAS for mapping snow depth: lessons learnt and outlook}

UASs have interesting potentialities within the framework of available methods to reconstruct the spatial variability of snow surface. In fact, they enable us to obtain semiautomated, quick, and repeatable surveys of limited areas, with a quite high vertical precision. Although the device that we used here needs the operator to assist it during take-off operations, other devices (currently not available to the au-
Table 3. Comparison between the snow volume via UAS $V_{\mathrm{UAS}}=$ $463652.3 \mathrm{~m}^{3}$ and the one obtained via spatialization techniques $\left(V_{\mathrm{T}}\right)$.

\begin{tabular}{lcc}
\hline Technique & $V_{\mathrm{T}}\left(\mathrm{m}^{3}\right)$ & $V_{\mathrm{UAS}}-V_{\mathrm{T}}\left(\mathrm{m}^{3}\right)$ \\
\hline Arith.c mean & 369146.3 & 94505.9 \\
IDW & 368216.9 & 95435.3 \\
Thiessen & 363400.5 & 100251.7 \\
Kriging & 368433.1 & 95219.2 \\
\hline
\end{tabular}

thors) can take off and land in a semi-automated way, and can cover much wider areas. This could let repeated (say, daily) surveys to be autonomously obtained, even without needing an operator to reach the target area. This, together with the possibility to substitute, or integrate, optical sensors with sensors at different wavelengths, could represent in the future an alternative to automated point stations to directly obtain distributed measurements of snow variables.

Results by Vander Jagt et al. (2015) and Bühler et al. (2016) were obtained using multi-rotor systems. These devices have the clear advantage of a higher stability to strong winds. Moreover, they can take off and land along a vertical direction and this is advantageous in mountain areas. On the other hand, battery duration is restricted and this is a major drawback since maximizing areal extension is important when using UAS in hydrologic applications given the extension (and spatial variability) of the processes investigated. This has been the main reason why we initially chose a fixed-wing device. From an operational point of view, using a fixed-wing UAS in Alpine areas means that the success of the survey is highly dependent on fair and stable weather conditions. This may cause frequent failures in surveys due to, e.g., unexpected changes in weather conditions. However, note that attempts have been already made to design supports that could resist harsh climatic conditions (Funaki et al., 2008) - conditions which would make unfeasible a survey using the same sensor used here. Other challenges include the possible absence of satellites signal or reduced battery duration due to air temperature effects.

Future developments of this work should compare the performance of this technique during multi-year study cases in different snow conditions and using more extensive data sets of snow depth data for evaluation purposes. The main reason is that this test has been performed during just 1 day, and at one location, in order to provide a preliminary assessment of the feasibility of using UASs to retrieve snow depth over a limited area. No evident limitation hampers the use of these devices over larger areas, apart from battery duration, or within areas characterized by patchy snow cover conditions. On the other hand, different weather conditions (such as precipitation events, or scarce visibility), different snow cover conditions (such as shallow snow covers) and/or different topographic patterns could have an impact on the 
performance of these devices that must be still assessed. A shallow snow cover (say, snow depth lower than $20 / 30 \mathrm{~cm}$ ) is likely to be difficult to be measured correctly given the standard deviation we found here $(12.8 \mathrm{~cm})$, whereas unexpected vegetation represents an important challenge and source of errors or ambiguity that must be carefully addressed in future investigations. This problem may be partially solved by using optical data to detect snow-covered areas, only. An additional challenge is represented by moving glacier surfaces, that may hamper DSM differentiation. Moreover, scarce visibility can potentially undermine a photogrammetry-based survey given the difficulties in detecting the ground (or snow) surface from an elevation of around $100 \mathrm{~m}$ during, e.g., fog events or intense rainfalls (or snowfalls). We suggest a multi-site multitemporal framework like that performed by, e.g., Nolan et al. (2015) as a possible future development of this work. Similar analyses using UAS are still lacking: an evidence is given by the sparse literature on this topic that is nowadays growing within cryospheric sciences (Lucieer et al., 2014; Vander Jagt et al., 2015; Bühler et al., 2016; Di Mauro et al., 2015; Fugazza et al., 2015; Ryan et al., 2015).

\section{Conclusions}

For the first time, we have here mapped snow depth variability at centimeter scale by means of a photogrammetrybased survey using fixed wing UAS over a small Alpine area $\left(\sim 0.3 \mathrm{~km}^{2}\right)$. For this purpose, we performed two surveys. The first one, during September 2013, enabled us to reconstruct ground topography. This survey will not be necessary for future assessments of snow distribution in the same area. Then, during April 2014, a second survey enabled us to reconstruct the variability of snow depth, by vertical differentiation of the maps.

Results show that: (1) the orthophoto and DSM of autumn survey are in agreement with the topographic map available for the study area (standard deviation of the differences between these two DSMs is $1.63 \mathrm{~m}$ ); (2) the average difference between manual and UAS-based measurements of snow depth (and the associated standard deviation) seems competitive with the typical precision of point measurements and other distributed techniques (the average difference obtained is equal to $-7.3 \mathrm{~cm}$, with an associated standard deviation of $12.8 \mathrm{~cm}$ ). The overall RMSE is equal to $0.143 \mathrm{~m}$; (3) the standard deviation (and CV) across the study area increases with decreasing spatial sampling distances, but stabilizes below $1 \mathrm{~m}$ resolution, thus suggesting the existence of a possible compromise between increasing spatial resolution of surveys and the amount of significant information obtained for hydrological applications.
Acknowledgements. The authors thank A2A for the logistic support during the setup of the experiment. We would like to thank Riccardo Capetti and Amilcare Marchetti (A2A) for their assistance during field activities. We would like to thank the Editor, Philip Marsh, Steven R. Fassnacht, Davide Bavera, and two anonymous referees for their feedback on the paper.

Edited by: P. Marsh

\section{References}

Agisoft: Agisoft PhotoScan User Manual Professional Edition, Version 1.1, 2014.

Anderton, S. P., White, S. M., and Alvera, B.: Evaluation of spatial variability in snow water equivalent for a high mountain catchment, Hydrol. Process., 18, 435-453, doi:10.1002/hyp.1319, 2004.

Avanzi, F., De Michele, C., Ghezzi, A., Jommi, C., and Pepe, M.: A processing modeling routine to use SNOTEL hourly data in snowpack dynamic models, Adv. Water Resour., 73, 16-29, 2014.

Bavay, M., Lehning, M., Jonas, T., and Löwe, H.: Simulations of future snow cover and discharge in Alpine headwater catchments, Hydrol. Process., 23, 95-108, doi:10.1002/hyp.7195, 2009.

Bavay, M., Grünewald, T., and Lehning, M.: Response of snow cover and runoff to climate change in high Alpine catchments of Eastern Switzerland, Adv. Water Resour., 55, 4-16, doi:10.1016/j.advwatres.2012.12.009, 2013.

Bavera, D., Bavay, M., Jonas, T., Lehning, M., and De Michele, C.: A comparison between two statistical and a physically-based model in snow water equivalent mapping, Adv. Water Resour., 63, 167-178, doi:10.1016/j.advwatres.2013.11.011, 2014.

Blöschl, G. and Kirnbauer, R.: An Analysis of snow cover patterns in a small alpine catchment, Hydrol. Process., 6, 99-109, doi:10.1002/hyp.3360060109, 1992.

Bühler, Y., Adams, M. S., Bösch, R., and Stoffel, A.: Mapping snow depth in alpine terrain with unmanned aerial systems (UAS): potential and limitations, The Cryosphere Discuss., doi:10.5194/tc2015-220, in review, 2016.

Carroll, S. S. and Cressie, N.: Spatial modeling of snow water equivalent using covariances estimated from spatial and geomorphic attributes, J. Hydrol., 190, 42-59, doi:10.1016/S00221694(96)03062-4, 1996.

Cline, D., Elder, K., and Bales, R.: Scale effects in a distributed snow water equivalence and snowmelt model fir mountain basins, Hydrol. Process., 12, 1527-1536, 1998.

Colomina, I. and Molina, P.: Unmanned Aerial Systems for Photogrammetry and Remote Sensing: a review, ISPRS J. Photogramm., 92, 79-97, doi:10.1016/j.isprsjprs.2014.02.013, 2014.

Dadic, R., Mott, R., Lehning, M., and Burlando, P.: Wind influence of snow depth distribution and accumulation over glaciers, J. Geophys. Res., 115, F01012, doi:10.1029/2009JF001261, 2010.

Deems, J. S., Fassnacht, S. R., and Elder, K. J.: Fractal Distribution of Snow Depth from Lidar Data, J. Hydrometeorol., 7, 285-297, doi:10.1175/JHM487.1, 2006. 
Deems, J. S., Painter, T. H., and Finnegan, D. C.: Lidar measurement of snow depth: a review, J. Glaciol., 59, 467-479, doi:10.3189/2013JoG12J154, 2013.

De Michele, C., Avanzi, F., Ghezzi, A., and Jommi, C.: Investigating the dynamics of bulk snow density in dry and wet conditions using a one-dimensional model, The Cryosphere, 7, 433-444, doi:10.5194/tc-7-433-2013, 2013.

Delacourt, C., Allemand, P., Jaud, M., Grandjean, P., Deschamps, A., Ammann, J., Cuq, V., and Suanez, S.: DRELIO: An Unmanned Helicopter for Imaging Coastal Areas, J. Coastal Res., Special Issue, 56, 1489-1493, 2009.

Di Mauro, B., Fava, F., Ferrero, L., Garzonio, R., Baccolo, G., Delmonte, B., and Colombo, R.: Mineral dust impact on snow radiative properties in the European Alps combining ground, UAV and satellite observations, J. Geophys. Res.-Atmos., 120, 60806097, doi:10.1002/2015JD023287, 2015.

Dietz, A. J., Kuenzer, C., Gessner, U., and Dech, S.: Remote sensing of snow - a review of available methods, Int. J. Remote Sens., 33, 4094-4134, doi:10.1080/01431161.2011.640964, 2012.

Dressler, K. A., Leavesley, G. H., Bales, R. C., and Fassnacht, S. R.: Evaluation of gridded snow water equivalent and satellite snow cover products for mountain basins in a hydrologic model, Hydrol. Process., 20, 673-688, doi:10.1002/hyp.6130, 2006.

Dunford, R., Michel, K., Gagnage, M., Piegay, H., and Tremelo, M. L.: Potential and constraints of Unmanned Aerial Vehicle technology for the characterization of Mediterranean riparian forest, Int. J. Remote Sens., 30, 4915-4935, 2009.

Eisenbeiss, H.: UAV Photogrammetry, 194, Institute of Geodesy and Photogrammetry, ETH Zürich, 2009.

Elder, K., Rosenthal, W., and Davis, R. E.: Estimating the spatial distribution of snow water equivalence in a montane watershed, Hydrol. Process., 12, 1793-1808, 1998.

Erxleben, J., Elder, K., and Davis, R.: Comparison of spatial interpolation methods for estimating snow distribution in the Colorado Rocky Mountains, Hydrol. Process., 16, 3627-3649, doi:10.1002/hyp.1239, 2002.

Farinotti, D., Magnusson, J., Huss, M., and Bauder, A.: Snow accumulation distribution inferred from time-lapse photography and simple modelling, Hydrol. Process., 24, 2087-2097, doi:10.1002/hyp.7629, 2010.

Fassnacht, S. R., Dressler, K. A., and Bales, R. C.: Snow water equivalent interpolation for the Colorado River Basin from snow telemetry (SNOTEL) data, Water Resour. Res., 39, 1208, doi:10.1029/2002WR001512, 2003.

Fierz, C., Armstrong, R., Durand, Y., Etchevers, P., Greene, E., McClung, D., Nishimura, K., Satyawali, P., and Sokratov, S.: The International Classification for Seasonal Snow on the Ground, Tech. rep., IHP-VII, Technical Documents in Hydrology No. 83, IACS Contribution No. 1, UNESCO - IHP, Paris, 2009.

Fugazza, D., Senese, A., Azzoni, R. S., Smiraglia, C., Cernuschi, M., Severi, D., and Diolaiuti, G. A.: High resolution mapping of glacier surface features. The UAV survey of the Forni Glacier (Stelvio National Park, Italy), Geogr. Fis. Din. Quat., 38, 25-33, 2015.

Funaki, M., Hirasawa, N., and the Ant Plane Group: Outline of a small unmanned aerial vehicle (Ant-Plane) designed for Antarctic research, Polar Sci., 2, 129-142, 2008.

Grünewald, T. and Lehning, M.: Are flat-field snow depth measurements representative? A comparison of selected index sites with areal snow depth measurements at the small catchment scale, Hydrol. Process., 29, 1717-1728, doi:10.1002/hyp.10295, 2015.

Grünewald, T., Schirmer, M., Mott, R., and Lehning, M.: Spatial and temporal variability of snow depth and ablation rates in a small mountain catchment, The Cryosphere, 4, 215-225, doi:10.5194/tc-4-215-2010, 2010.

Grünewald, T., Stötter, J., Pomeroy, J. W., Dadic, R., Moreno Baños, I., Marturià, J., Spross, M., Hopkinson, C., Burlando, P., and Lehning, M.: Statistical modelling of the snow depth distribution in open alpine terrain, Hydrol. Earth Syst. Sci., 17, 3005-3021, doi:10.5194/hess-17-3005-2013, 2013.

Hedrick, A., Marshall, H.-P., Winstral, A., Elder, K., Yueh, S., and Cline, D.: Independent evaluation of the SNODAS snow depth product using regional-scale lidar-derived measurements, The Cryosphere, 9, 13-23, doi:10.5194/tc-9-13-2015, 2015.

Hood, J. L. and Hayashi, M.: Assessing the application of a laser rangefinder for determining snow depth in inaccessible alpine terrain, Hydrol. Earth Syst. Sci., 14, 901-910, doi:10.5194/hess14-901-2010, 2010.

Hopkinson, C., Sitar, M., Chasmer, L., and Treitz, P.: Mapping snowpack depth beneath forest canopies using airborne lidar, Photogramm. Eng. Rem., 70, 323-330, 2004.

Hopkinson, C., Collins, T., Anderson, A., Pomeroy, J., and Spooner, I.: Spatial Snow Depth Assessment Using LiDAR Transect Samples and Public GIS Data Layers in the Elbow River Watershed, Alberta, Can. Water Resour. J., 37, 69-87, doi:10.4296/cwrj3702893, 2012.

Hugenholtz, C. H., Whitehead, K., Brown, O. W., Barchyn, T. E., Moorman, B. J., LeClair, A., Riddell, K., and Hamilton, T.: Geomorphological mapping with a small unmanned aircraft system (sUAS): Feature detection and accuracy assessment of a photogrammetrically-derived digital terrain model, Geomorphology, 194, 16-24, doi:10.1016/j.geomorph.2013.03.023, 2013.

Koh, L. P. and Wich, S. A.: Dawn of drone ecology: low-cost autonomous aerial vehicles for conservation, Trop. Conserv. Sci. 5, 121-132, 2012.

König, M. and Sturm, M.: Mapping snow distribution in the Alaskan Arctic using aerial photography and topographic relationships, Water Resour. Res., 34, 3471-3483, doi:10.1029/98WR02514, 1998.

Koutsoudis, A., Vidmar, B., Ioannakis, G., Arnaoutoglou, F., Pavlidis, G., and Chazmas, C.: Multi-image 3D reconstruction data evaluation, J. Cult. Herit., 15, 73-79, 2014.

Lehning, M., Völksch, I., Gustafsson, D., Nguyen, T. A., Stähli, M., and Zappa, M.: ALPINE3D: a detailed model of mountain surface processes and its application to snow hydrology, Hydrol. Process., 20, 2111-2128, doi:10.1002/hyp.6204, 2006.

Lehning, M., Löwe, H., Ryser, M., and Raderschall, N.: Inhomogeneous precipitation distribution and snow transport in steep terrain, Water Resour. Res., 44, W07404, doi:10.1029/2007WR006545, 2008.

Lehning, M., Grünewald, T., and Schirmer, M.: Mountain snow distribution governed by an altitudinal gradient and terrain roughness, Geophys. Res. Lett., 38, L19504, doi:10.1029/2011GL048927, 2011.

Lejot, J., Delacourt, C., Piégay, H., Fournier, T., Trémélo, M. L., and Allemand, P.: Very high spatial resolution imagery for channel bathymetry and topography from an unmanned mapping controlled platform, Earth Surf. Proc. Land., 32, 1705-1725, 2007. 
López-Moreno, J. I. and Nogués-Bravo, D.: Interpolating local snow depth data: an evaluation of methods, Hydrol. Process., 20, 2217-2232, doi:10.1002/hyp.6199, 2006.

López-Moreno, J. I., Fassnacht, S. R., Beguería, S., and Latron, J. B. P.: Variability of snow depth at the plot scale: implications for mean depth estimation and sampling strategies, The Cryosphere, 5, 617-629, doi:10.5194/tc-5-617-2011, 2011.

López-Moreno, J. I., Fassnacht, S. R., Heath, J. T., Musselman, K. N., Revuelto, J., Latron, J., Móran-Tejeda, E., and Jonas, T.: Small scale spatial variability of snow density and depth over complex alpine terrain: Implications for estimating snow water equivalent, Adv. Water Resour., 55, 40-52, 2013.

López-Moreno, J. I., Revuelto, J., Fassnacht, S. R., Azorín-Molina, C., Vicente-Serrano, S. M., Morán-Tejeda, E., and Sexstone, G. A.: Snowpack variability across various spatio-temporal resolutions, Hydrol. Process., 29, 1213-1224, 2015.

Lucieer, A., Turner, D., King, D. H., and Robinson, S. A.: Using an Unmanned Aerial Vehicle (UAV) to capture micro-topography of Antarctic moss beds, Int. J. Appl. Earth Obs., 27, 53-62, 2014.

Luzi, G., Noferini, L., Mecatti, D., Macaluso, G., Pieraccini, M., Atzeni, C., Schaffhauser, A., Fromm, R., and Nagler, T.: Using a Ground-Based SAR Interferometer and a Terrestrial Laser Scanner to Monitor a Snow-Covered Slope: Results From an Experimental Data Collection in Tyrol (Austria), IEEE T. Geosci. Remote, 47, 382-393, doi:10.1109/TGRS.2008.2009994, 2009.

Marsh, C. B., Pomeroy, J. W., and Spiteri, R. J.: Implications of mountain shading on calculating energy for snowmelt using unstructured triangular meshes, Hydrol. Process., 26, 1767-1778, doi:10.1002/hyp.9329, 2012.

Ménard, C. B., Essery, R., and Pomeroy, J.: Modelled sensitivity of the snow regime to topography, shrub fraction and shrub height, Hydrol. Earth Syst. Sci., 18, 2375-2392, doi:10.5194/hess-182375-2014, 2014.

Meromy, L., Molotch, N. P., Link, T. E., Fassnacht, S. R., and Rice, R.: Subgrid variability of snow water equivalent at operational snow stations in the western USA, Hydrol. Process., 27, 23832400, 2013.

Molotch, N. P., Fassnacht, S. R., Bales, R. C., and Helfrich, S. R.: Estimating the distribution of snow water equivalent and snow extent beneath cloud cover in the Salt - Verde River basin, Arizona, Hydrol. Process., 18, 1595-1611, doi:10.1002/hyp.1408, 2004.

Morin, S., Lejeune, Y., Lesaffre, B., Panel, J.-M., Poncet, D., David, P., and Sudul, M.: An 18-yr long (1993-2011) snow and meteorological dataset from a mid-altitude mountain site (Col de Porte, France, $1325 \mathrm{~m}$ alt.) for driving and evaluating snowpack models, Earth Syst. Sci. Data, 4, 13-21, doi:10.5194/essd-4-13-2012, 2012.

Mott, R., Scipión, D., Schneebeli, M., Dawes, N., and Lehning, M.: Orographic effects on snow deposition patterns in mountainous terrain, J. Geophys. Res., 119, 1419-1439, doi:10.1002/2013JD019880, 2014.

Nolan, M., Larsen, C., and Sturm, M.: Mapping snow depth from manned aircraft on landscape scales at centimeter resolution using structure-from-motion photogrammetry, The Cryosphere, 9, 1445-1463, doi:10.5194/tc-9-1445-2015, 2015.

Parajka, J. and Blöschl, G.: Validation of MODIS snow cover images over Austria, Hydrol. Earth Syst. Sci., 10, 679-689, doi:10.5194/hess-10-679-2006, 2006.
Pollefeys, M., Koch, R., and Van Gool, L.: Self-calibration and metric reconstruction in spite of varying and unknown internal camera parameters, in: IJCV, Sixth International Conference on Computer Vision, Bombay, India, 90-95, doi:10.1109/ICCV.1998.710705, 1999.

Prokop, A., Schirmer., M., Rub, M., Lehning, M., and Stocker, M.: A comparison of measurement methods: terrestrial laser scanning, tachymetry and snow probing for the determination of the spatial snow-depth distribution on slopes, Ann. Glaciol., 49, 210-216, doi:10.3189/172756408787814726, 2008.

Remondino, F.: Detectors and descriptors for photogrammetric applications, ISPRS Archives, 36, 49-54, 2006.

Remondino, F. and El-Hakim, S.: Image-based 3D modelling: a review, The Photogrametric Record, 21, 269-291, 2006.

Rice, R. and Bales, R. C.: Embedded-sensor network design for snow cover measurements around snow pillow and snow course sites in the Sierra Nevada of California, Water Resour. Res., 46, W03537, doi:10.1029/2008WR007318, 2010.

Ryan, J. C., Hubbard, A. L., Box, J. E., Todd, J., Christoffersen, P., Carr, J. R., Holt, T.'O., and Snooke, N.: UAV photogrammetry and structure from motion to assess calving dynamics at Store Glacier, a large outlet draining the Greenland ice sheet, The Cryosphere, 9, 1-11, doi:10.5194/tc-9-1-2015, 2015.

Ryan, W. A., Doesken, N. J., and Fassnacht, S. R.: Evaluation of Ultrasonic Snow Depth Sensors for U.S. Snow Measurements, J. Atmos. Ocean. Tech., 25, 667-684, doi:10.1175/2007JTECHA947.1, 2008.

Serreze, M. C., Clark, M. P., Armstrong, R. L., McGinnis, D. A., and Pulwarty, R. S.: Characteristics of the western United States snowpack from snowpack telemetry (SNOTEL) data, Water Resour. Res., 35, 2145-2160, doi:10.1029/1999WR900090, 1999.

Skaugen, T.: Modelling the spatial variability of snow water equivalent at the catchment scale, Hydrol. Earth Syst. Sci., 11, 15431550, doi:10.5194/hess-11-1543-2007, 2007.

Sona, G., Pinto, L., Pagliari, D., Passoni, D., and Gini, R.: Sperimental analysis of different software packages for orientation and digital surface modelling from UAV images, Earth Sci. Inform., 7, 97-107, doi:10.1007/s12145-013-0142-2, 2014.

Stretcha, C., Pylyänäinen, T., and Fua, P.: Dynamic and scalable large scale image reconstruction, in: IEEE Conference on Computer Vision and Pattern Recognition, San Francisco, USA, 406413, doi:10.1109/CVPR.2010.5540184, 2010.

Vander Jagt, B., Lucieer, A., Wallace, L., Turner, D., and Durand, M.: Snow Depth Retrieval with UAS Using Photogrammetric Techniques, Geosciences, 5, 264-285, 2015.

Verhoeven, G.: Software Review - Taking Computer Vision Aloft Archaeological Three-dimensional Reconstructions from Aerial Photographs with PhotoScan, Archaeol. Prospect., 18, 67-73, 2011.

Watts, A. C., Ambrosia, V. G., and Hinkley, E. A.: Unmanned Aircraft Systems in Remote Sensing and Scientific Research: Classification and Considerations of Use, Remote Sensing, 4, 16711692, doi:10.3390/rs4061671, 2012.

Worby, A. P., Markus, T., Steer, A. D., Lytle, V. I., and Massom, R. A.: Evaluation of AMSR-E snow depth product over East Antarctic sea ice using in situ measurements and aerial photography, J. Geophys. Res., 113, C05S94, doi:10.1029/2007JC004181, 2008. 